\title{
Assessment of innovative development of the regional economy by multiple analysis methods
}

\author{
Guzel Salimova ${ }^{1,1}$, Alisa Ableeva ${ }^{1}$, Gulnara Nigmatullina $^{1}$, Aigul Galimova ${ }^{2}$ and Ramzilya \\ Bakirova $^{3}$ \\ ${ }^{1}$ Bashkir State Agrarian University, 450001, Ufa, Russian Federation \\ ${ }^{2}$ Bashkir State University, 450076, Ufa, Russian Federation \\ ${ }^{3}$ Financial University under the Government of the Russian Federation, Ufa branch, 450015, Ufa, \\ Russian Federation
}

\begin{abstract}
The article studies the system of indicators characterizing the innovative development of regions. A hierarchical classification of the subjects of the Volga Federal District of the Russian Federation by indicators characterizing the results of innovative activities of organizations, including agricultural enterprises, has been performed. A comparative analysis of the regions by the level of innovative development is carried out. Regularities are revealed, prospects for further development are determined. For each cluster, promising areas of innovative economic development are identified. The connection of science and production, leading to innovative development, is shown.
\end{abstract}

\section{Introduction}

Improvement of the methodology for assessing the nature and degree of intensity of innovative development of the economy of a country and regions, the practice of its application is becoming more important and relevant. The modern development of the world, society and economy requires further innovative development of the economy of the country and regions in its composition.

Future of the global economy depends more and more on possibilities and restrictions of innovative development [1]. There is strong evidence that innovation is a primary driver of a nation's economic growth [2].

In the classical interpretation economic development is limited by non-renewable nature of a significant part of the natural resource potential and assimilation abilities of the environment [1]. This is especially true for the agricultural sector, where land is the main means of production, and climatic conditions determine the characteristics of production. However, it is noted that it's safe to say that the impact of innovative-technological factors, based on scientific, educational and information revolutions, powered by the synergic effect of the partnership of civilizations, is rising. [1]

The intensification of innovations required system approach, which resulted in creation of national innovation systems. They are designed to support and ensure innovation

${ }^{1}$ Corresponding author: salimovaguzel@mail.ru 
processes, including creation of favorable conditions for interaction of their different actors (various kinds of business; universities; scientific institutions; state) [3].

Scientists talk about the need to move to a more efficient economic system that will encourage manufacturers to develop innovative solutions to reduce production waste, efficient use of resources [4]. It is about introducing environmental safety innovations. The health of the nation largely depends on the socio-economic and living conditions of the person, including the ecology of nutrition. This leads to the development of innovative technical solutions aimed at ensuring the quality of food products [5].

It should be noted the proposed prospects and directions in the organization of innovative economic development. One possible way is to develop a cluster policy [1]. It has a great influence on the strategic development of the region. Creation and development of regional clusters is accompanied by quick distribution of innovational products and effective exchange of information between its participants [6]. For example, Silicon Valley amazes the world with scientific and technological innovations. She is a representative of global innovation capital and the industrial cluster [7].

Analysis requires an information base. Statistics of innovations in the Russian Federation allows studying the demand and offer for the results of innovative activity and conducting evaluation of the production and scientific potential of the economy, distribution of financing, and other factors, necessary for development of innovative activity in Russia [8].

The purpose of this article is to study the level of innovative development of the economy, including agriculture, in the regions of the Volga Federal District, to develop recommendations and promising areas.

\section{Materials and Methods}

A multidimensional grouping of the regions of the Volga Federal District of the Russian Federation was carried out using the cluster analysis method to study the level of innovative development. Clusters were identified by indicators characterizing innovative activity in the regions. The sources of information were official statistics [9]. 33 indicators were calculated and selected from statistical indicators characterizing the innovative development of regional economies. They are conditionally combined into 3 groups (Table $1)$.

Table 1. The system of indicators of innovative development of the regions

\begin{tabular}{|c|c|}
\hline Indicator groups & The name of indicators \\
\hline \multirow{5}{*}{$\begin{array}{l}\text { Indicators of } \\
\text { scientific } \\
\text { potential }\end{array}$} & Research and development institutions, percent of their total number \\
\hline & Research and development personnel, people per 100 organizations \\
\hline & $\begin{array}{l}\text { Researchers with advanced degrees, percent in research and development } \\
\text { personnel }\end{array}$ \\
\hline & $\begin{array}{l}\text { Gross domestic expenditure on research and development, million rubles per } \\
1 \text { research and development institution }\end{array}$ \\
\hline & $\begin{array}{l}\text { Share of scientific disciplines (fields of science) in the total cost of research } \\
\text { and development, percent; natural; engineering; medical; agricultural; } \\
\text { social; humanities }\end{array}$ \\
\hline \multirow{4}{*}{$\begin{array}{l}\text { Indicators of } \\
\text { resources and } \\
\text { costs for } \\
\text { innovative } \\
\text { development }\end{array}$} & $\begin{array}{l}\text { Share of costs of technological innovations in total volume of shipped goods, } \\
\text { performed work, services, percent }\end{array}$ \\
\hline & $\begin{array}{l}\text { Share of certain types in the intramural current expenditures of research and } \\
\text { development, percent: labour costs; equipment }\end{array}$ \\
\hline & $\begin{array}{l}\text { Share of certain types in capital costs of research and development, percent: } \\
\text { on information, computer and telecommunication equipment; on computer } \\
\text { programs }\end{array}$ \\
\hline & $\begin{array}{l}\text { Share of research and development costs in the intramural current } \\
\text { expenditures, percent: on basic research; on applied research; on experimental }\end{array}$ \\
\hline
\end{tabular}




\begin{tabular}{|l|l|}
\hline \multirow{5}{*}{$\begin{array}{l}\text { Innovation } \\
\text { performance }\end{array}$} & $\begin{array}{l}\text { development. } \\
\text { Use of Internet in organizations, percent of total number of surveyed } \\
\text { organizations }\end{array}$ \\
\cline { 2 - 2 } & $\begin{array}{l}\text { Active subscribers of mobile broadband access to the Internet, per 100 } \\
\text { population }\end{array}$ \\
\cline { 2 - 2 } & $\begin{array}{l}\text { Intility models } \\
\text { marketing, organizational innovations as a percentage of all enterprises) }\end{array}$ \\
\hline & Sales of innovative goods and services, percent of total sales \\
\cline { 2 - 2 } & $\begin{array}{l}\text { Organizations engaged in innovation, providing better environmental safety in } \\
\text { the production of goods, works and services, as a percent of the total number } \\
\text { of organizations engaged in environmental innovation, including: } \\
\text { reduction of material costs, energy costs for the production of a unit of goods, } \\
\text { work, services; } \\
\text { carbon dioxide emission reduction; } \\
\text { replacement of raw materials with safe or less dangerous; } \\
\text { environmental pollution reduction; } \\
\text { recycling of production waste, water or materials; } \\
\text { conservation and reproduction of natural resources used by agriculture }\end{array}$ \\
\cline { 2 - 2 } Labour productivity as percent of previous year \\
\cline { 2 - 2 } $\begin{array}{l}\text { Share of captured and neutralized air pollutants in the total amount of } \\
\text { pollutants from stationary sources, percent }\end{array}$ \\
\hline
\end{tabular}

Cluster analysis was performed using the program «STATISTICA 6.0». The classification used standardized coefficients. Hierarchical dendrogram built for 14 regions of the Volga Federal District. The most stable results were obtained using the full coupling method, the Euclidean distance metric.

\section{Results and Discussion}

Data set is analyzed for 2018. Clustering showed a general picture of the unification of regions into clusters, diverse in the level of innovative development of the economy (Figure 1).

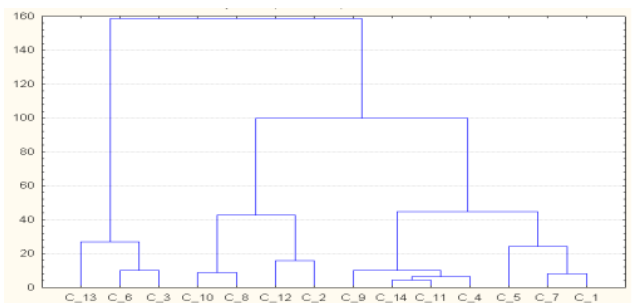

Fig. 1. Dendrogram of the regions of the Volga Federal District of the Russian Federation

Separation of the Volga Federal District in the clusters obtained as a result of research. Groups are presented in Table 2.

Table 2. Characteristics of the clusters of the regions of the Volga Federal District of the Russian Federation by level of innovative development of the economy

\begin{tabular}{|c|l|}
\hline Cluster & \multicolumn{3}{|c|}{ The composition of the clusters } \\
\hline I & Saratov Region, Republic of Mordovia, Chuvash Republic \\
\hline II & Kirov Region, Orenburg Region, Samara Region, Republic of Mari El \\
\hline III & $\begin{array}{l}\text { Nizhny Novgorod Region, Penza Region, Ulyanovsk Region, Republic of } \\
\text { Bashkortostan, Republic of Tatarstan, Udmurtian Republic, Perm Territory }\end{array}$ \\
\hline
\end{tabular}


The first cluster is represented by 3 which is $21,4 \%$ of the total number of the studied totality. The second cluster contains 4 regions $(28,6 \%)$. The third cluster is the most representative and contains 7 regions. The indicators in the clusters take on very different values.

Cluster 1 is characterized by the largest share of research and development institutions, $(0,126$ percent of their total number). At the same time, it has the largest among the groups indicator of the share of social sciences in the total cost of research and development $(7,5 \%)$. The greatest innovation activity of organizations observed in this cluster $(14,1 \%)$, highest labor productivity index. On the impact of innovation on the environment in the region of the cluster marked by the largest proportion of trapped and destroyed air pollutants, the largest proportion of organizations engaged in innovation to ensure the preservation and reproduction of use of natural resources in agriculture.

Cluster 2 is characterized by the largest share of researchers with advanced degrees in their total number $(16,9 \%)$. The largest share of natural, medical, agricultural, humanities in the total cost of research and development is observed in the second cluster. Such concentration and proportions of scientific research give the result in the form of the largest share of expenditures among groups of regions for basic research $(24,5 \%)$, the largest number of patents granted per 100 research and development institutions: for inventions $(683,0)$ and utility models $(345,5)$. At the same time, there is a low level of implementation of scientific research in production (for example, among clusters there is the lowest level of innovative activity of organizations - $6,8 \%$, the smallest volume of innovative goods, works, services $-7,1 \%$ ). However, the largest participation of organizations is achieved in reducing energy costs for the production of a unit of production, in reducing emissions of carbon dioxide into the atmosphere. They are the most high-tech and science-intensive spheres in the field of ecology.

Cluster 3 is characterized by a more practical application of scientific research. So, in this group there is the largest number of research and development personnel (18,1people per 100 organizations), the largest Gross domestic expenditure on research and development (296,1 million rubles per one research and development institution). The largest costs among clusters are in technical sciences $(82,9 \%)$. Much of the cost is aimed at technological innovation $3,1 \%$ of total volume of shipped goods, performed work, services), on experimental development $(77,5 \%$ of intramural current expenditures on research and development). Moreover, there is the largest share of organizations that use of Internet $(92,8 \%$ of total number of surveyed organizations) in this cluster, the largest number of active subscribers of mobile broadband access to the Internet $(81,1$ per 100 population). As result are the largest sales of innovative goods and services (13,6\% of total sales). Cluster 3 organizations involved in environmental innovation are more working to reduce environmental pollution and recycle waste.

In general, the regions of the Volga Federal District, as well as the Russian Federation as a whole, are characterized by the largest share of expenses for engineering sciences among other fields of science, and therefore, on experimental development. Currently, in the context of the development of the digital economy and digital technologies, this indicates the greatest interest and the greatest demand for technical innovative devices, machines. Innovative activity of organizations of Russian regions $8,5 \%$. Sales of innovative goods and services is $6,5 \%$ of total sales. Organizations working on innovations in environmental safety are more focused on reducing environmental pollution $(78,4 \%)$, reducing energy costs $(51,0 \%)$, and waste recycling $(43,4 \%)$.

About industry differences, for example, innovations in the field of agricultural production, in our opinion, it should be noted the impossibility of differentiating scientific research by type of economic activity, since the sphere of interests of agriculture can relate to various scientific disciplines and fields of science. Discoveries made in one field of 
science also affect agricultural production. $13.8 \%$ of organizations involved in environmental safety innovations in Russia work on the conservation and reproduction of resources used by agriculture.

Results of other studies confirm the findings of scientists that businesses are more likely to innovate if they collaborate, have higher information and communication technology intensity, and use science, technology, engineering and mathematics skills [2]. This is consistent with our findings regarding the use of multiple indicators.

Analysis of international experience in the sphere of formation of regional clusters according to the dirigisme and liberal models and application of the global experience in development of cluster approach during realization of strategic development of regions shows the possibilities for creation of clusters in the Russian conditions in view of adaptation technologies. The main peculiarities of the modern cluster policy in the Russian Federation include large influence of the state and low level of development of business climate and spatial structure of economy [6]. The creation and development of clusters for the purpose of innovation development of economy is very timely and relevant. In this regard, the results obtained in the article are practically significant, have a scientific novelty. Transformation of economy greatly enhanced by the agglomeration, that create and develop innovative assets [10]. In our study, we also reasonably did not divide the sectors of the economy. The synergistic effect also takes place to be. Currently, substantial attention is focused on innovations presenting smart solutions. Their purpose rests in efficiency, economy, environmental friendliness, safety (including health) $[11,12]$.

Scientists talk about the need to move to a more efficient economic system that would encourage producers to develop innovative solutions to reduce production waste, be in the line of "green" production and resource-efficient usage. This system would help to solve problems of resource shortage, negative environmental impact, production and consumption waste by developing closer relationships between suppliers, manufacturers, retailers and consumers. [4] The need for and the development of environmentally friendly production requires the correct economic organization. The role of the university is crucial, fostering and developing an innovative, intelligent and with values entrepreneurship [13]. Scientists highlight the increasing importance of education in innovation processes and changed requirements to it, which causes respective changes in curricula, organizational models and approaches to external cooperation with science and business [3]. Economic growth, the development of techniques and technology, is possible thanks to the development of human capital, which is closely contribution to science. The contribution of education to labor productivity growth is estimated in different studies to be between $13 \%$ and $30 \%$ of the total increase. Through education, development and investment in human capital we create an innovative society that will develop innovative activities and lead to economic growth [14]. Universities play an important role in innovative ecosystems. [15]. Studies show a negative correlation between the size of a company and the efficiency of knowledge production, and a positive correlation with the effectiveness of knowledge commercialization [16].

\section{Conclusion}

The regions of Cluster 1 have great scientific potential, which is recommended to be directed towards practical implementation, work with enterprises. The regions of Cluster 2 are encouraged to actively introduce numerous existing inventions into production, cooperation of scientific organizations with neighboring regions, exchange of experience, work with business. The regions of Cluster 3 is recommended to actively use and implementation of technology in the sectors of the economy, especially in agriculture, which is already actively going. Prospective studies will be at the intersection of 
disciplines, which will lead to unexpected innovation and breakthroughs, including functional food.

The classification of the system of indicators of innovative development from the position of cluster analysis was first performed. Cluster analysis is an informative method of research innovation development of economy. Further development of the methodology of the study, we see in the construction of the integral index of the innovative development of regions. Also promising are studies multiple grouping of enterprises by economic activity engaged in innovation, highlighting the agriculture.

\section{References}

1. N. Gagulina, I. Zhulega, A. Samoylov, SHS Web of Conferences, 74, 02005 (2019)

2. F. Soriano, R. Villano, E. Fleming, Australian j. Agricult. and resource economics, 63, 39-71 (2019).

3. O. Kolomytseva, A. Pavlovska. Baltic j. Econ.studies, 6, 51-58 (2020).

4. J. Stankeviciene, M. Nikanorova, G. Cera, Gentjan. E \& M Ekonomie a Management, 23, 4-18 (2020).

5. E. M.Basarygina, A. V.Shershnev, T. A.Putilova, Conference on Ecological Agriculture and Sustainable Development, 216-225 (2019)

6. N. Golikova, T. Bezrukova, N. Safonova, Advances in Intelligent Systems and Computing, 726, 546-553 (2018)

7. W. Pan, L.Jian, D. Wang, IEEE International Conference on Grey Systems and Intelligent Services (GSIS), 360-366 (2019).

8. L. Oveshnikova, E. Sibirskaya, S. Kulikova, Advances in Intelligent Systems and Computing, 726, 80-861 (2018).

9. Official website of the Federal state statistics service of the Russian Federation, URL: www.gks.ru.

10. D. Brzica. 2nd CEFE, 119-127 (2017)

11. I.Gabitov, I.Badretdinov, S.Mudarisov, E.Khasanov, R. Lukmanov, R.Nasyrov, M.Tuktarov, D.Atnagulov, I.Timeriashev, V. Pavlenko, J. Eng. and Appl, S.13, 6517$6526(2018)$

12. J. Parobek, E. Loucanova, M.Olsiakova, SHS Web of Conferences, 74, 02011 (2019)

13. J.Francisco, E. Marti, E. Ribera, Ciriec-Espanarevistadeeconomiapublica social y cooperativa. 98, 31-57 (2020)

14. K. Wierzbicka, 5th RSEP International Conferences on Social Issues and Economic Studies, 207-214 (2017)

15. S. Heaton, D. Siegel, D. Teece, Industrial and corporate change. 28, 921-939 (2019)

16. Y.Li, Z. Zhong, J. Guan, Asian journal of technology innovation. 28, 94-118 